\title{
c-N2 非小細胞肺癌（NSCLC）に対する
}

\section{Induction Chemoradiotherapy（ICRT)}

\author{
横見瀬裕保 1 岡本 卓 1 黄 政龍 1 - 山本恭通 ${ }^{1} \cdot$ \\ 石川真也 ${ }^{1} \cdot$ 中島 尊 $^{1} \cdot$ 栘谷大輝 1 後藤正司 1 - \\ 劉 大革 $1 \cdot$ 藤田次郎 $2 \cdot$ 板東修二 ${ }^{2} \cdot$ 石田俊彦 $^{2} \cdot$ 住友伸一 $^{3}$
}

要旨一一 目的. c-N2 非小細胞肺癌（non-small cell lung cancer: NSCLC）の治療成績は極めて不良である.この結果を 改善するために我々は導入化学放射線療法（induction chemoradiotherapy: ICRT）を行っている. 対象と方法. 1992 年 1 月から 2004 年 4 月までに c-N2 NSCLC 50 例に ICRT を行った. 1998 年までは MVP あるいは EP (n= 27, A 群)を 使用し，1999 年以降は Taxan + CBDCA $(\mathrm{Tx}+\mathrm{P})(\mathrm{n}=23 ， \mathrm{~B}$ 群)を使用した。 それぞれ 2 クールと $50 \mathrm{~Gy}$ の放射線を同 時併用し手術を施行した。結果. 全例完全切除が可能で手術関連死亡はなかった．奏効率は $74 \%$ であった. Ef 2 ある いは 3 は全体で 38 例（76\%）あった.Ef 3 （組織学的完全寛解）は 10 例（20\%）であった３年生存率（3 生）は $54 \%$ であった. B 群における Ef 3 症例の 3 生は 80\%で 3 例が 40 ケ月以上無再発生存中である. 結論. c-N2 NSCLC に対す る ICRT 後の手術は安全に行われ結果は有望であった. 良好な組織学的効果を示した症例では良い結果が期待できる. (肺癌. 2005;45:275-279)

索引用語 — c-N2 非小細胞肺癌 (NSCLC), 導入化学放射線療法 (ICRT), 組織学的効果

\section{Induction Chemoradiotherapy for c-N2 Non-Small Cell Lung Cancer}

\author{
Hiroyasu Yokomise ${ }^{1}$; Taku Okamoto ${ }^{1}$; Cheng-Long Huang ${ }^{1}$; Yasumichi Yamamoto'; \\ Shinya Ishikawa ${ }^{1}$; Takashi Nakashima ${ }^{1}$; Daiki Masuya ${ }^{1}$; Masashi Gotoh ${ }^{1}$; \\ Dage Liu'; Jiro Fujita ${ }^{2}$; Shuji Bandoh²; Toshihiko Ishida ${ }^{2}$; Shinichi Sumitomo ${ }^{3}$
}

\begin{abstract}
Objectives. The therapeutic results for c-N2 non-small cell lung cancer (NSCLC) are extremely bad. To improve these results, we performed induction chemoradiotherapy (ICRT). Materials and methods. 50 patients with c-N2 NSCLC underwent operation following ICRT from January 1992 to April 2004. Until 1998, MVP (mitomycin C, vindesine, cisplatin) or EP (etoposide, cisplatin) $(\mathrm{n}=27$, group-A). After that, Taxan + CBDCA (carboplatin) $(\mathrm{Tx}+\mathrm{P})$ $(\mathrm{n}=23$, group-B). Two cycles of chemotherapy were performed with concurrent radiation $(50 \mathrm{~Gy})$. Results. In all 50 cases, complete resection was performed with no operative mortality. Response rate was $74 \%$. Histological response rate of $\mathrm{Ef} 2$ or $\mathrm{Ef} 3$ was $78 \%$ (38 cases of 50 cases). Complete histological response was observed in 10 cases $(20 \%)$. Three-year survival was $54 \%$. Three-year survival of Ef 3 patients in group B $(\mathrm{Tx}+\mathrm{p})$ was $80 \%$ and three patients survived more than 40 months. Conclusions. Surgery after ICRT for c-N2 NSCLC could be performed safely with promising results. Better outcome is anticipated for patients who exhibit good histological response. (JJLC. 2005;45:275-279)
\end{abstract}

KEY WORDS — c-N2 non-small cell lung cancer (NSCLC), Induction chemoradiotherapy (ICRT), Pathological effect

香川大学医学部 1第二外科, 2 第一内科 ; 3 日本赤十字社和歌山医 療センター呼吸器外科.

別刷請求先：横見瀬裕保, 香川大学医学部第二外科, $\overline{\mathbf{T}} 761-0793$ 香川県木田郡三木町池辺 1750-1 (e-mail: yokomise@kms.ac.jp).

${ }^{1}$ Second Department of Surgery, ${ }^{2}$ First Department of Internal Medicine, Kagawa University School of Medicine, Japan; ${ }^{3}$ Depart- ment of Thoracic Surgery, Japanese Red Cross Wakayama Medical Center, Japan.

Reprints: Hiroyasu Yokomise, Second Department of Surgery, Kagawa University School of Medicine, 1750-1 Ikenobe, Miki-cho, Kita-gun, Kagawa 761-0793, Japan（e-mail: yokomise@kms.ac.jp) .

(C) 2005 The Japan Lung Cancer Society 


\section{はじめに}

c-N2 の 非 小細 胞肺癌 (non-small cell lung cancer: NSCLC）に対する手術単独の治療成績が極めて不良なこ とは広く知られており, ${ }^{1}$ Roth $ら,{ }^{2}$ Rosell $ら^{3}$ の報告以 来, 術前導入化学療法後の手術がこの病期の一つの治療 法として選択されている。一方，切除不能で根治的胸部 放射線治療が可能な局所進行 NSCLCには化学放射線療 法 (chemoradiotherapy: CRT) を行うことが強く勧められ ているが, 4 c-N2 NSCLC に対する導入化学放射線療法 (induction chemoradiotherapy: ICRT) の有効性について は明らかではなかった。しかし2003 年のASCOにおけ る Intergroup Trial 0139（RTOG 93-09）の報告は ICRT 後の外科療法の有効性を初めて示唆した. 5 我々は以前 より c-N2 NSCLC に対し ICRT 後に手術を試みているの でその結果，外科療法の妥当性について報告する。

\section{対象と方法}

1992 年 1 月から 2004 年 4 月までに日本赤十字社和歌 山医療センター，香川大学第 2 外科で ICRT 後に手術を 行った c-N2 NSCLC 50 例を対象とした.N2 は胸部 CT 上短径 $2 \mathrm{~cm}$ 以上のリンパ節を転移有りとした。 2002 年 4 月からはPET も N2 の診断に併用した. PET 画像上描 出されていた部分が肉眼的に消失した場合を完全寛解と した. Eligibility criteria を Figure 1 に示す. 男性 47 例， 女性 3 例，年齢は 37〜 75 歳 $(61 \pm 9.9)$ であった。組織型 は腺癌 16 例, 扁平上皮癌 32 例, 大細胞癌 2 例であった. c-stage は IIIA 期 39 例, IIIB 期 11 例であった. 1998 年ま では MVP: $n=17$ あるいは EP: $n=10$ (n=27, A 群) を使 用し，1999 年以降は新規抗癌剤である Taxan + CBDCA paclitaxel: $\mathrm{n}=12$, docetaxel: $\mathrm{n}=11 （ \mathrm{n}=23$, B 群) を使 用した。それぞれ 2 クールと $50 \mathrm{~Gy}$ の放射線を同時併用 し手術を施行した (Figure 2). 化学療法の詳細は Figure 3 に示す.

\section{結 果}

全例完全切除が可能で手術関連死亡はなかった. 白血 球において Grade 4 の副作用が A 群で 7 例 (20.6\%)，B 群で 3 例 $(13.0 \%)$ 観察されたが G-CFS の投与で対処可 能であった。手術術式は肺摘除が 11 例，肺葉切除が 39 例に行われた。レントゲン的な奏効率は全体で $74 \%$ ， A 群 $83 \%$, B 群 $65 \%$ であった. 組織学的効果としては Ef 2 あるいは 3 は全体で 38 例 $(76 \%), \mathrm{A}$ 群 19 例 $(73 \%), \mathrm{B}$ 群 19 例（83\%）であった.Ef 3（組織学的完全寛解）は 10 例 $(20 \%)$, A 群 5 例 $(18 \%)$, B 群 5 例 (22\%) であっ た。全体の 3 年生存率（3 生）は $54.4 \%$ で A 群，B群に 差はなかった (Figure 4，5)。Ef 2 以上の症例の 5 年生存

\section{Eligibility Criteria of Induction Therapy for c-N2 NSCLC}

1. Pathologically proven stage IIIA IIIB NSCLC

2. $\mathrm{c}-\mathrm{N} 2$ : a short-axis diameter of more than $2 \mathrm{~cm}$ on chest $\mathrm{CT}$

3. No prior therapy

4. $\mathrm{PS} 0-2$

5. Less than 75 years old

6. $\mathrm{Ccr} \geqq 50 \mathrm{ml} / \mathrm{h}$

7. Surgery tolerable in terms of cardiac and pulmonary function

Figure 1. Eligibility criteria.

\section{Therapeutic schedule}

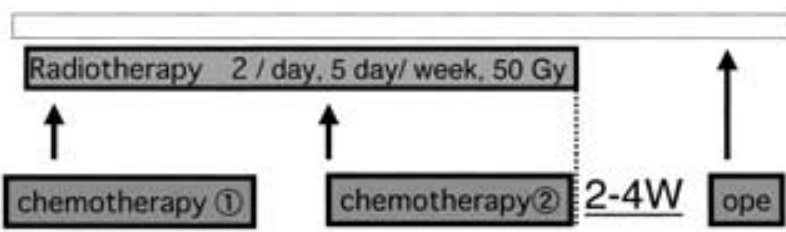

Group A: MVP or PE

Group B: TXL or TXT + CBDCA

Figure 2. Therapeutic schedule.

\section{Menu for chemotherapy}

$\begin{array}{cl}\text { Group A } \\ \text { MVP: } & \begin{array}{l}\text { cisplatin } \\ \text { mitomycin } \\ \text { vindesine }\end{array} \\ \text { PE: } \quad \begin{array}{l}\text { cisplatin } \\ \text { etoposide }\end{array} \\ \text { Group B } \\ \text { TXL: } & 180 \mathrm{mg} / \mathrm{m}^{2} \\ \text { CBDCA (AUC 6) } \\ \text { TXT: } & 60 \mathrm{mg} / \mathrm{m}^{2} \\ & \text { CBDCA (AUC 6) }\end{array}$

Figure 3. Menu for chemotherapy.

率は全体で 44.1\%であったが Ef1b に長期生存は得られ なかった (Figure 6). Ef 2 以上の症例の 3 生は A 群 52\%, B 群 $62 \%$ であった (Figure 7). B 群における Ef 3 症例の 


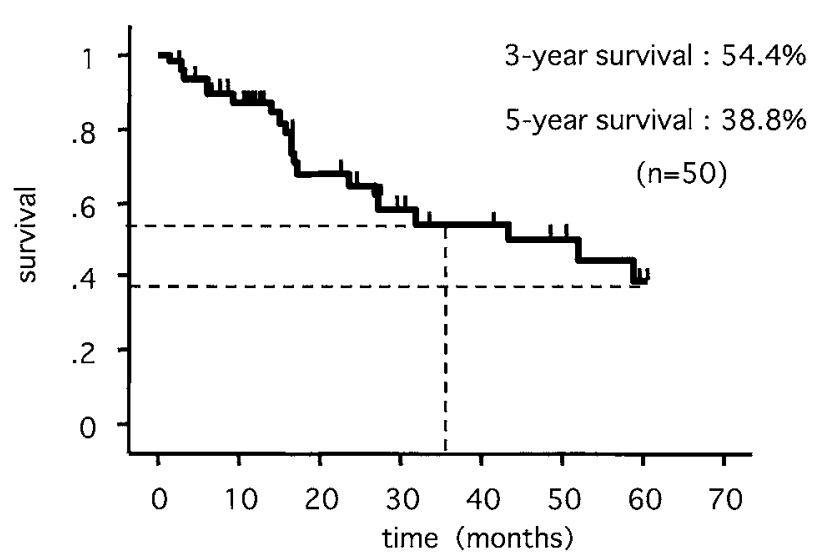

Figure 4. Overall survival for 50 patients.

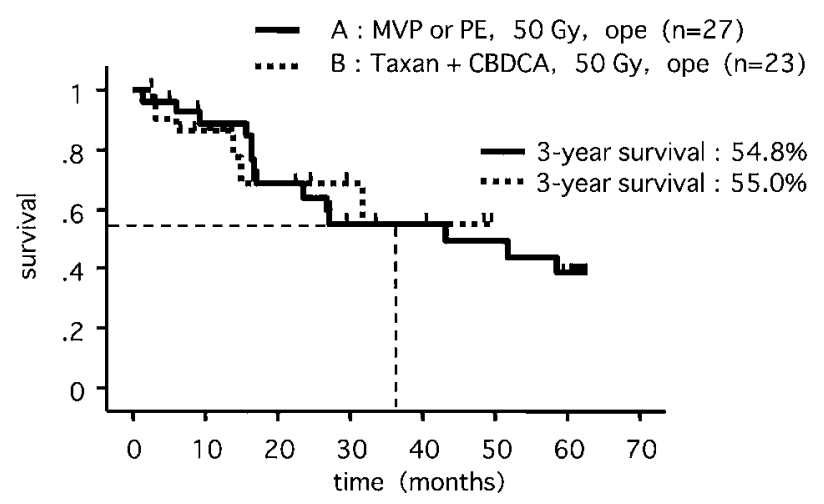

Figure 5. Overall survival according to chemotherapy.

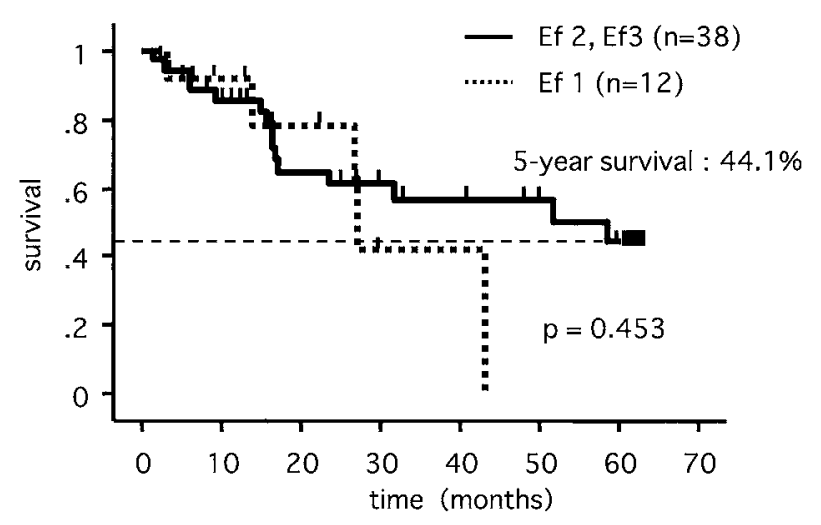

Figure 6. Overall survival according to pathological response.

3 生は $80 \%$ で 3 例が 40 ケ月以上無再発生存中である (Figure 8).

\section{PET による効果判定}

主病巣における standardized uptake value (SUV) の減 弱率は Ef 2, Ef 3 において Ef1bより有意に高值であっ たが $(\mathrm{p}<0.001, \mathrm{p}=0.026), \mathrm{Ef} 2$ と Ef 3 を術前に判断す

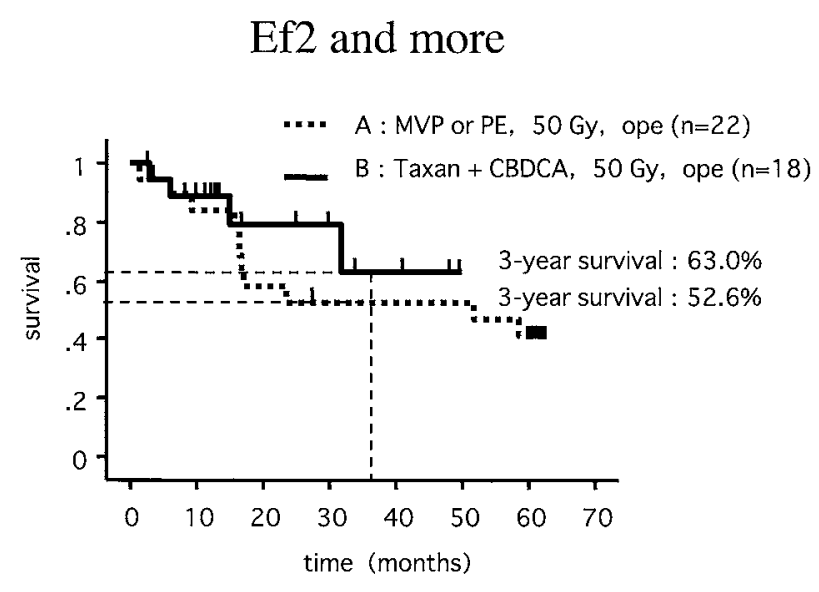

Figure 7. Overall survival according to chemotherapy in Ef 2 and more.

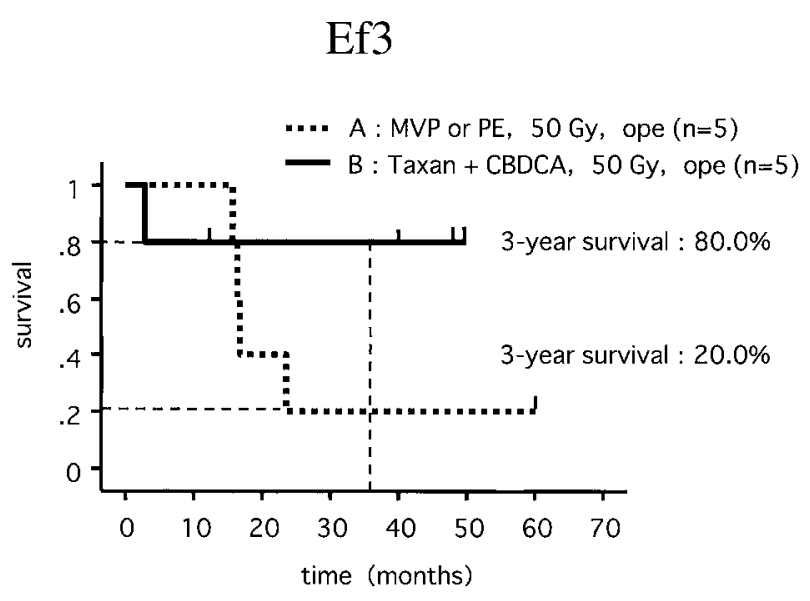

Figure 8. Overall survival according to chemotherapy in Ef 3.

ることは困難であった (Figure 9). ICRT のリンパ節にお ける効果判定においても SUV は Ef 2 以上で有意に低 かった (Figure 10). 症例を提示する (Figure 11). CT および PET で気管分岐部リンパ節 (\#7) 陽性と判断され た扁平上皮癌症例において, 術後リンパ節転移は認めら れなかった。

\section{考 察}

Roth ら, ${ }^{2}$ Rosell $ら^{3}$ の報告以来, 手術可能な c-N2 NSCLCに対する導入化学療法はこの病状に対する一つ の治療方法として試みられてきた. 導入化学放射線療法 に関しては Straussらは CDDP, VLB, 5-Fluorouracil (FU) による化学療法と放射線治療 $30 \mathrm{~Gy}$ の同時併用を 行い，41 例中 4 例 $(9.8 \%)$ に組織学的完全寛解を得，9 例 $(21.5 \%)$ が長期生存した. ${ }^{6} \mathrm{EP}$ を軸とした $40 \mathrm{~Gy}$ を超 


\section{before induction after induction}
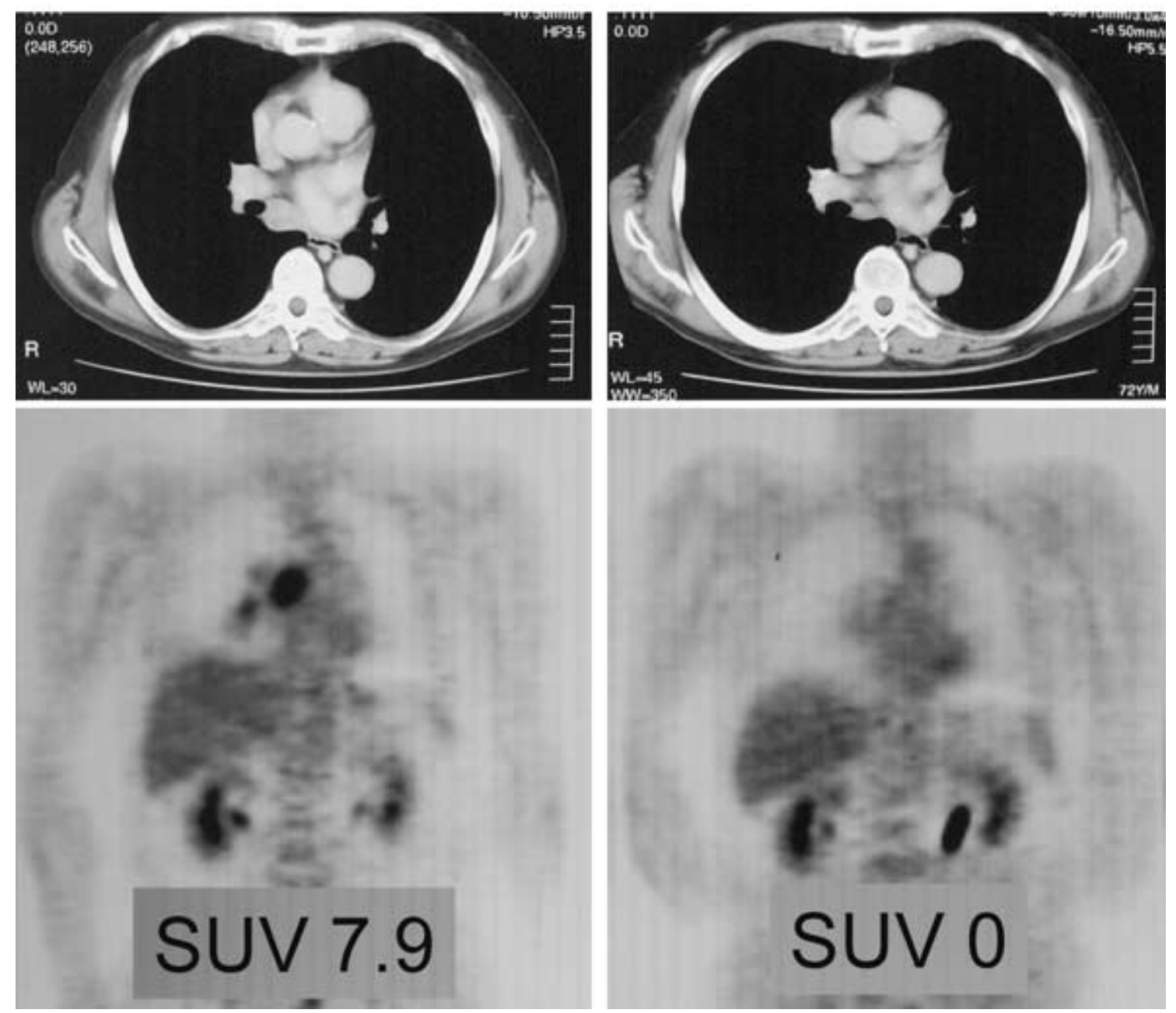

Figure 9. The findings of CT and PET before and after ICRT; \# 7 lymph node decreased in size and disappeared on PET scan.

\begin{tabular}{|c|c|c|c|c|c|c|}
\hline & $n$ & pre-SUV & post-SUV & \multicolumn{3}{|c|}{ SUV decrease rate } \\
\hline Ef1b & 2 & $7.26 \pm 0.51$ & $5.53 \pm 0.87$ & $0.24 \pm 0.07$ & \multirow{3}{*}{ * } & \\
\hline Ef2 & 12 & $10.44 \pm 3.57$ & $2.81 \pm 1.04$ & $0.72 \pm 0.09$ & & $\dagger$ \\
\hline Ef3 & 2 & $9.60 \pm 6.10$ & $1.63 \pm 0.18$ & $0.80 \pm 0.11$ & & \\
\hline & 16 & $9.94 \pm 3.61$ & $3.00 \pm 1.41$ & $0.67 \pm 0.19$ & & \\
\hline${ }^{\star} p<0$. & 001 & $\dagger p=0.026$ & & & & \\
\hline
\end{tabular}

Figure 10. Relationship between SUV and pathological response to ICRT in the primary tumor. 


\begin{tabular}{ccccc} 
& $n$ & pre-SUV & post-SUV & SUV decrease rate \\
\hline Ef1b & 2 & $6.26 \pm 1.95$ & $\left.\left.\begin{array}{l}3.32 \pm 0.72 \\
+ \\
0.64 \pm 1.72\end{array}\right]+\begin{array}{l}0.44 \pm 0.21 \\
0.86 \pm 0.25\end{array}\right] *$ \\
\hline Ef2.3 8 & $7.86 \pm 4.24$ & $0.77 \pm 0.30$ \\
\hline 10 & $7.55 \pm 3.85$ & $1.15 \pm 1.60$ & $0.0 .1 p=0.63$
\end{tabular}

Figure 11. Relationship between SUV and pathological response to ICRT in lymph node.

える放射線照射を行う concurrent な化学放射線療法が IIIA 期以上の進行 NSCLC の治療の主流になりつつある が標準的治療法として確立されたわけではない. 7,8

しかし 2003 年の ASCO における Intergroup Trial 0139（RTOG 93-09）の報告は ICRT 後の外科療法の有効性 を初めて示唆した. 5

我々の行った ICRT は tolerableで手術関連死亡はな かった. 全例で完全切除が可能で 3 生は $54 \%$ であった. 特に Ef 2 以上の組織学的効果が得られた症例の生存率 は良好であった.Ef 3 の導入率は $20 \%$ 前後でそれらの生 存率はさらに良好であった。

1）切除によって長期予後が得られている Ef 2 症例に は腫瘍が遺残していたこと，2）Ef 3 （手術が必要でな かったかもしれない症例)の導入率が $20 \%$ 前後であるこ と，3）Ef 2 と Ef 3 を術前に判別することが困難なこと を考慮すると，外科療法に妥当性があると考えられる。

PETによる組織学的効果判定が術前に可能であれば ICRT で benefit が得られる症例（Ef 2, Ef 3）に対してだ け手術ができる可能性がある。

\section{REFERENCES}

1. Martini N, Kris MG, Flehinger BJ, et al. Preoperative chemotherapy for stage IIIa (N2) lung cancer: Sloan-Kettering experience with 136 patients. Ann Thorac Surg.1993;55: 1365-1373.

2. Roth JA, Fossella F, Komaki R, et al. A randomized trial comparing perioperative chemotherapy and surgery with surgery alone in resectable stage IIIA non-small-cell lung cancer. J Natl Cancer Inst. 1994;86:673-680.

3. Rosell R, Gomez-Codina J, Camps C, et al. A randomized trial comparing preoperative chemotherapy plus surgery with surgery alone in patients with non-small-cell lung cancer. N Engl J Med. 1994;330:153-158.

4. Kubota K, Furuse K, Kawahara M, et al. Role of radiotherapy in combined modality treatment of locally advanced non-small-cell lung cancer. J Clin Oncol.1994;12:15471552.

5. Albain KS, Scott CB, Rusch VR, et al. Phase III comparison of concurrent chemotherapy plus radiotherapy (CT/ $\mathrm{RT}$ ) and CT/RT followed by surgical resection for stage IIIA (pN2) non-small cell lung cancer (NSCLC): Initial results from intergroup trial 0139 (RTOG 93-09). Proc Am Soc Clin Oncol. 2003;22:621.

6. Strauss GM, Herndon JE, Sherman DD, et al. Neoadjuvant chemotherapy and radiotherapy followed by surgery in stage IIIA non-small-cell carcinoma of the lung: report of a Cancer and Leukemia Group B phase II study. J Clin Oncol.1992;10:1237-1244.

7. Thomas M, Rube C, Semik M, et al. Impact of preoperative bimodality induction including twice-daily radiation on tumor regression and survival in stage III non-small cell lung cancer. J Clin Oncol. 1999;17:1185-1193.

8. Stamatis G, Eberhardt W, Stuben G, et al. Preoperative chemoradiotherapy and surgery for selected non-small cell lung cancer IIIB subgroups: long-term results. Ann Thorac Surg. 1999;68:1144-1149. 